Optimization of cementitious composite for heavyweight concrete preparation using conduction calorimetry

DRAGOMIROVÁ, J.; PALOU, M.; KUZIELOVA, E.; ŽEMLIČKA, M.; NOVOTNÝ, R.; GMÉLING, K.

Journal of Thermal Analysis and Calorimetry

2020, vol. 142, pp. 255-266

ISSN 1588-2926

DOl: http://dx.doi.org/10.1007/s10973-020-09530-0

Accepted manuscript

(๔) Akadémiai Kiadó, Budapest, Hungary 2020

The final publication is available at Springer via http://dx.doi.org/10.1007/s10973-020-09530-0 


\title{
Optimization of cementitious composite for heavyweight concrete preparation using conduction calorimetry
}

Janette Dragomirová1,2, Martin T. Palou ${ }^{1,2}$, Eva Kuzielováa ${ }^{1,2}$, Matúš Žemlička ${ }^{1}$, Radoslav Novotný ${ }^{3} \&$ Katalin Gméling ${ }^{4}$

${ }^{1}$ Institute of Construction and Architecture, SAS, Dúbravská cesta 9, SK-845 03 Bratislava, Slovak Republic

${ }^{2}$ Faculty of Chemical and Food Technology, SUT, Radlinského 9, SK-812 37 Bratislava, Slovak Republic

${ }^{3}$ Materials Research Centre, Faculty of Chemistry, BUT, Purkyňova 118, CZ-612 00 Brno, Czech Republic

${ }^{4}$ Nuclear Analysis and Radiography Department, Centre for Energy Research, Hungarian Academy of Sciences, Konkoly Thege Miklós út 29-33. 1121, Budapest, Hungary

Published in the Journal of Thermal Analysis and Calorimetry 142, 255-266 (2020) https://doi.org/10.1007/s10973-020-09530-0

\begin{abstract}
The present work investigates the hydration heat of different cement composites by means of conduction calorimetry to optimize the composition of binder in the design of heavyweight concrete as biological shielding. For this purpose, Portland cement CEM I 42.5 R was replaced by a different portion of supplementary cementitious materials (blast furnace slag, metakaolin, silica fume/limestone) at 75\%, 65\%,60\%, 55\%, and 50\% levels to obtain low hydration heat lower than $250 \mathrm{j} \mathrm{g}^{-1}$. All ingredients were analyzed by energy dispersive X-ray fluorescence (EDXRF) and nuclear activation analysis (NAA) to assess the content of major elements and isotopes. A mixture of two high-density aggregates (barite and magnetite) was used to prepare three heavyweights concretes with compressive strength exceeding $45 \mathrm{MPa}$ and bulk density ranging between 3400 and $3500 \mathrm{~kg} \mathrm{~m}^{-3}$. After a short period of volume expansion (up to $4 \mathrm{~h}$ ), a slight shrinkage (max. $0.3^{\circ}{ }^{\circ}$ ) has been observed. Also, thermophysical properties (thermal conductivity, volumetric specific heat, thermal diffusivity) and other properties were determined. The results showed that aggregate content and not binder is the main factor influencing the engineering properties of heavyweight concretes.
\end{abstract}

\section{Introduction}

The convenient design of heavyweight concrete for a massive structure like biological shielding in nuclear power plant takes into account, not only the type of aggregates, chemical and mineralogical composition of each component as reported in $[1,2,3,4,5]$, but also the hydration heat and its rate must be carefully designated in order to avoid thermal stress, internal and external strain and surface thermal cracking $[6,7,8,9]$. Hydration heat of cementitious binders and its rate play key roles in the design of massive concrete structures due to the risk of thermal cracking. Indeed, the exothermic hydration reaction of cement generates fast heat rise in the core of concrete structure originating thus temperature difference with the concrete surface [6]. As a consequence of non-uniform heat distribution and thermal conductivity, the temperature gradient will cause tensile stress. When tensile stress is higher than the tensile strength, then thermal crack occurs on 
the surface of concrete or mortars [7, 8]. Moreover, shrinkage strains at the hardening period of cement paste or concrete can be observed [7]. Therefore, the characterization of generated heat of binders is of primary importance in order to avoid early thermal cracking risk in a concrete structure. Use of supplementary cementing materials (SCMs) such as granulated ground blast slag furnace, metakaolin, silica fume, and limestone, in manufacturing blended types of cement and concrete, reduces hydration heat $[10,11,12]$ and additionally improves the performances of the concrete. However, the substitution of cement by SCM lowers strength development at earlier curing period but contributes to the strength gain at long-term age. Therefore, blended types of cement corresponding to low-heat cement become suitable in the fabrication of massive heavyweight concretes. Next to hydration heat generated in the massive concrete structure, thermal characteristics such as thermal conductivity, specific heat, thermal diffusivity, shrinkage, and structural properties play an important role in the integrity, durability, and functionality of concrete. Indeed, massive structure as biological shielding around nuclear power reactors is exposed to gamma and neutron radiation [2,3,4,13]. Apart from hydration temperature, temperature due to irradiation effect can generate heat transfer from one side to the second. Moreover, heat transfer is a basic principle of thermal power station operation in a nuclear plant from the production of pressured hot water to the cooling equipment. The thermal properties of concrete used as biological shielding were studied and reported in $[14,15,16]$. Thermal conductivity, thermal diffusivity, and specific or volumetric heat capacity are some of the basic thermophysical properties that characterize the thermal performance of concrete structures $[17,18,19,20]$.

For application as biological shielding, proportioning and homogeneity of concrete composition are of great importance for both structural stability and attenuation capacity. Moreover, the presence of isotopes under certain irradiation could be a source of nuclear emission [21]. For this reason, the design of concrete takes into account, not only the concrete composition based on general rule of mix proportion calculation, but it must consider the presence of radioisotopes in ingredients due to their activation properties. Indeed, the most important source properties to consider are gamma-ray emission energy, activity, and half-life. The activity, A, defines the beam intensity and is expressed in $\mathrm{Bq}$ (Becquerel: emission per second) or the old unit $\mathrm{Ci}$ (Curie; $\mathrm{Ci}=3.7 \times 10^{10} \mathrm{~Bq}$ ). The half-time, $\mathrm{T}_{1 / 2}$, is the time it takes for the amount of radionuclides in the source to be halved.

Thermal properties of concrete structures

Thermal conductivity of concrete expresses its ability to conduct heat in a dispersed tridimensional axis. In a simplified form (Eq. 1), it is defined by Fourier's law [13]:

$$
q=-\frac{d T}{d x}
$$

where $q$ is heat flux $\left(\mathrm{W} \mathrm{m}^{-2}\right), \lambda$ thermal conductivity $\left(\mathrm{W} \mathrm{m}^{-1} \mathrm{~K}^{-1}\right), \mathrm{d} T$ is temperature difference in $\mathrm{K}$ or ${ }^{\circ} \mathrm{C}$ and $\mathrm{d} x$ the distance or thickness in $\mathrm{m}$.

Heat capacity and volumetric heat capacity 
In general definition, heat capacity is defined as the amount of heat needed to raise the temperature of a given mass by one degree, whereas specific heat capacity represents the capability to store energy. Heat capacity is the relation between heat content and resulting temperature change and can be calculated with Eq. 2:

$$
c_{v}=\frac{Q}{V \Delta T}
$$

where $c_{\mathrm{V}}$ is volumetric heat capacity $\left(\mathrm{J} \mathrm{m}^{-3} \mathrm{~K}\right), \mathrm{Q}$ is heat transferred to a sample $(\mathrm{J}), \mathrm{V}$ is the volume of the sample $\left(\mathrm{m}^{3}\right)$, and $\Delta \mathrm{T}$ is the resulting temperature change in $\mathrm{K}$ or ${ }^{\circ} \mathrm{C}$.

Volumetric heat capacity is related to specific heat capacity and density and can be calculated by Eq. 3:

$$
c_{v}=\rho c_{m}
$$

where $c_{\mathrm{v}}$ is volumetric heat capacity $\left(\mathrm{J} \mathrm{m}^{-3} \mathrm{~K}\right), \rho$ is the density of concrete $\left(\mathrm{kg} \mathrm{m}^{-3}, \mathrm{~g} \mathrm{~cm}^{-3}\right)$.

It is well known that concrete has low thermal conductivity compared to metallic materials which constitute an additional engineering benefit is use of concrete as biological shielding.

Thermal diffusivity

The ability of a material to store heat depends upon its thermal diffusivity, $\alpha$, which is an indicator of heat transmission through a material. In other words, the higher the thermal diffusivity, the quicker the heat transfers through a material. According to Eq. 4, it is defined in heat transfer analysis by thermal conductivity divided by density and specific heat capacity at constant pressure, in other words by volumetric heat capacity.

$$
\alpha=\frac{\lambda}{\rho c_{p}}
$$

where $\alpha$ is thermal diffusivity $\left(\mathrm{m}^{2} \mathrm{~s}^{-1}\right), \lambda$ is thermal conductivity $\left(\mathrm{W} \mathrm{m}^{-1} \mathrm{~K}^{-1}\right), c_{\mathrm{p}}$ is specific heat capacity $(\mathrm{J} \mathrm{kg} \mathrm{K}), \rho$ is density $\left(\mathrm{kg} \mathrm{m}^{-3}\right)$.

Many studies interested in the study of thermophysical properties of concrete were related to energy storage because of heating or cooling of buildings [17,18,19,20,21,22], and there is little research on thermal conductivity of heavyweight concrete. It is well known that cooling and heating, and thermal comfort depend greatly on the constituents of building materials $[18,19,20]$.

The thermal performance of materials is evaluated according to their thermal conductivity, volumetric heat capacity, thermal diffusivity, etc.

The goal of the present study is to design heavyweight concrete, which can meet the functional and performance requirements of a radiation shielding material, with proven low activation and high mechanical properties. From the elemental composition of the raw material, it is possible to 
forecast the activation properties of the concrete in preparation. For this reason, nuclear elemental analytical techniques were used, as these techniques inmate the real situation of activation of the sample in a nuclear reactor.

\section{Experimental part}

Chemical analysis of all ingredients was performed by energy dispersive X-ray fluorescence (EDXRF) method using SPECTRO XEPOS HE spectrometer with the following configuration: operating voltage range 95-120 V/200-240 V/50/60 Hz, spectrometer power input $150 \mathrm{~W}$, X-ray tube $\mathrm{W}$-anode, and SDD detector Peltier cooling system.

The nuclear analytical methods (neutron activation analysis - NAA and prompt-gamma activation analysis - PGAA) were realized at Department of Nuclear Analysis and Radiography of the Centre for Energy Research from Hungarian Academy of Sciences [18]. The main advantages of these methods are to provide the concentration of isotope nuclides in samples before they can be used in the preparation of HWC for biological shielding. Isotopes with half-life longer than a month, but less than a year (e.g.: ${ }^{141} \mathrm{Ce},{ }^{181} \mathrm{Hf},{ }^{59} \mathrm{Fe},{ }^{124} \mathrm{Sb},{ }^{85} \mathrm{Sr},{ }^{160} \mathrm{~Tb},{ }^{46} \mathrm{Sc},{ }^{182} \mathrm{Ta},{ }^{65} \mathrm{Zn}$ ), with very long half-life $\left(\mathrm{T}_{1 / 2}\right):{ }^{134} \mathrm{Cs}\left(\mathrm{T}_{1 / 2}=2.07 \mathrm{y}\right),{ }^{60} \mathrm{Co}\left(\mathrm{T}_{1 / 2}=5.27 \mathrm{y}\right),{ }^{154} \mathrm{Eu}\left(\mathrm{T}_{1 / 2}=8.5 \mathrm{y}\right)$, and ${ }^{152} \mathrm{Eu}\left(\mathrm{T}_{1 / 2}=13.5\right.$ y) were considered. They are the most important in case of studying the activation properties of concretes.

Optimization of cementitious composite was performed by TAM AIR 8-Channel isothermal calorimeter consisting of an eight channel couples (sample and reference) based on heat flow and cumulative heat $[10,11,12,13]$.

The density of materials was determined by gas pycnometry technique Pentapyc 5200e Automatic from Quantachrome Instruments (UK), and specific surface area was measured by permeability Blaine test according to STN EN 196-6.

Mercury intrusion porosimeter Quantachrome Poremaster 60GT (Quantachrome UK Limited) was used for the analysis of the pore structure parameters of the composites. Two or three pieces of the dried sample with diameter less than $10 \mathrm{~mm}$ and total mass max. $2 \mathrm{~g}$ were used for the tests. The maximum applied pressure of mercury was $414 \mathrm{MPa}$, equivalent to a Washburn pore radius of $1.8 \mathrm{~nm}$.

Bulk density of fresh and dry mortars, dynamic modulus of elasticity, shrinkage, strengths (compressive and tensile, lateral compressive and cubic) were determined according to European standard EN12390-5 [10]. The static modulus of elasticity was measured on $100 \times 100 \times 500 \mathrm{~mm}$ prism specimens. The dynamic modulus of elasticity was performed on the same specimens prepared for static modulus using Ultrasonic Meter Matest.

The thermal properties (thermal conductivity, thermal capacity, and thermal diffusivity) were assessed using an ISOMET 2114 device as described in detail in [15].

In this research, three mixtures of heavyweight concrete were prepared. Aggregate mix comprised barite (SABAR, s.r.o., Slovakia) and magnetite (LKAB Minerals, Sweden) at the mass ratio of 
65/35 was used. Aggregates (barite and magnetite) were separately sieved into different size fractions and remixed to obtain aggregate mixtures with a defined grading curve falling into the region of standard grading curves (Fig. 1). The nominal maximum size of coarse aggregates was 16 mm. Portland cement (EXTRACEM CEM I 42.5 R CRH Slovensko a.s. Rohožník'), granulated blast furnace slag (Kotouč Štramberk, spol. s r.o., Czech Republic), metakaolin (metakaolin L05 Mefisto from České lupkové závody, a.s., Czech Republic), limestone (Calmit, spol. s.r.o., Slovakia), tape water , and superplasticizer (Stachement $2025 \mathrm{SP}$; density $1065 \mathrm{~kg} \mathrm{~m}^{-3}$, dry matter content $30 \pm 1.5 \%$, and $\mathrm{pH}$ value 5.0-8.0) in an amount of $0.6 \mathrm{~kg}$ per $100 \mathrm{~kg}$ ) were used to prepare concrete mix.

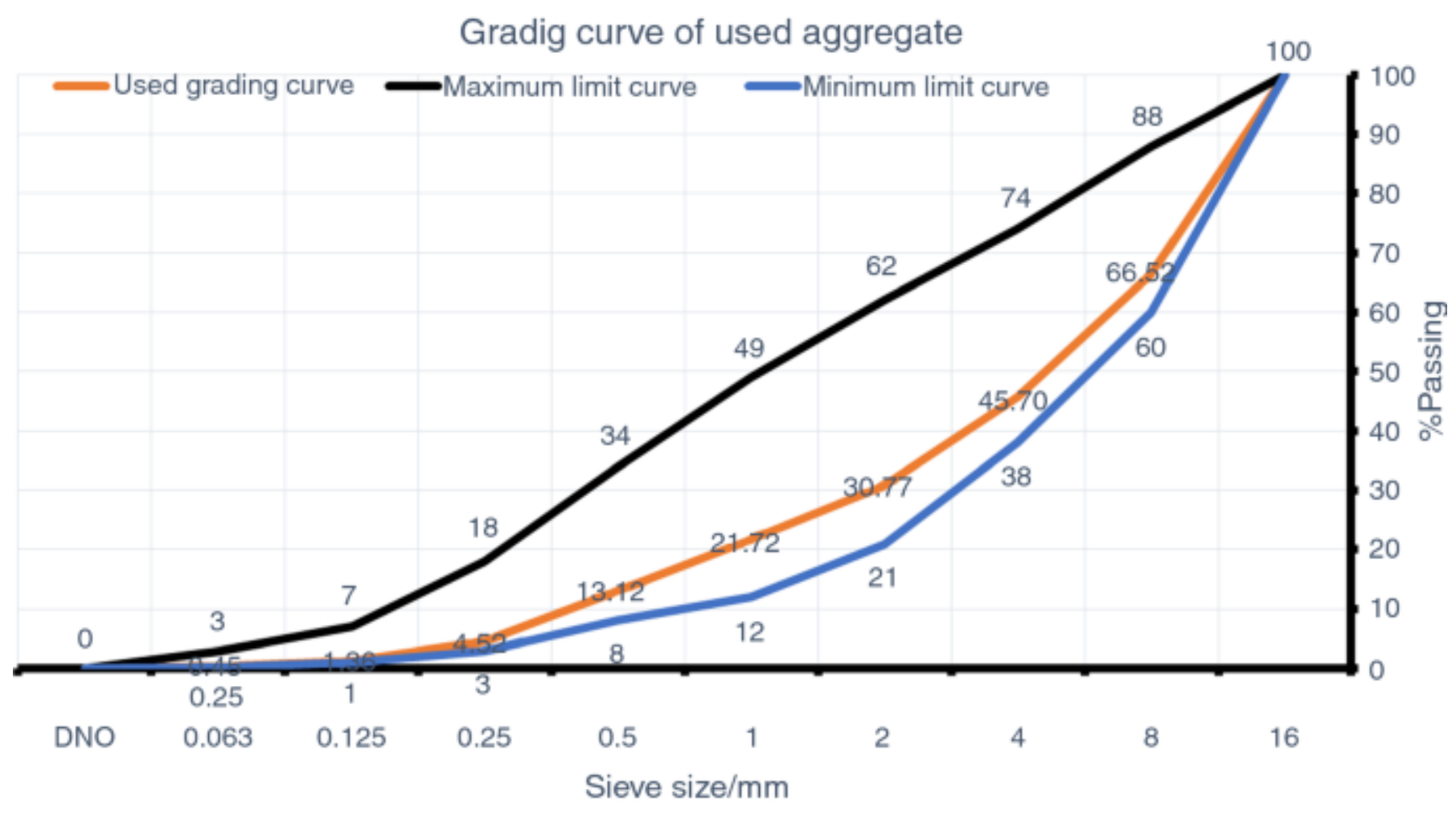

\section{Fig 1. Grading curve}

The oxide composition of different fractions of aggregates is reported in Table 1. Likewise, oxide composition of CEM I 42.5 R, granulated blast furnace slag, metakaolin, and limestone is depicted in Table 2 . 
Table 1 The oxide composition of heavy aggregates determined by XRF

Chemical composition of aggregates ( $\%$ by mass) according to different fraction

\begin{tabular}{|c|c|c|c|c|c|c|c|}
\hline $\begin{array}{l}\text { Chemical } \\
\text { element }\end{array}$ & $\begin{array}{l}\text { Barite } \\
\text { concentrate }\end{array}$ & $\begin{array}{l}\text { Barite } \\
0 / 4\end{array}$ & $\begin{array}{l}\text { Barite } \\
4 / 8\end{array}$ & $\begin{array}{l}\text { Barite } \\
\text { 8/16 }\end{array}$ & $\begin{array}{l}\text { Magnetite } \\
0 / 2\end{array}$ & Magnetite 0/8 & $\begin{array}{l}\text { Magnetite } \\
0 / 20\end{array}$ \\
\hline $\mathrm{SiO}_{2}$ & 0.70 & 4.79 & 5.55 & 4.68 & 0.80 & 4.00 & 3.00 \\
\hline $\mathrm{Al}_{2} \mathrm{O}_{3}$ & 0.14 & 0.81 & 0.67 & 0.34 & 0.28 & 0.70 & 0.40 \\
\hline $\mathrm{Fe}_{2} \mathrm{O}_{3}$ & 1.48 & 22.40 & 21.30 & 18.40 & - & - & - \\
\hline $\mathrm{Fe}_{3} \mathrm{O}_{4}$ & - & - & - & - & 97.60 & 89.70 & 90.80 \\
\hline $\mathrm{CaO}$ & 0.27 & 0.37 & 0.33 & 0.27 & 0.20 & 2.50 & 2.50 \\
\hline $\mathrm{MgO}$ & 0.18 & 1.40 & 1.29 & 1.13 & - & - & - \\
\hline $\mathrm{TiO}_{2}$ & 0.01 & 0.06 & 0.06 & 0.04 & - & - & - \\
\hline $\mathrm{MnO}$ & 0.07 & 1.03 & 0.96 & 0.93 & - & - & - \\
\hline $\mathrm{K}_{2} \mathrm{O}$ & 0.03 & 0.21 & 0.18 & 0.09 & 0.02 & 0.20 & 0.20 \\
\hline $\mathrm{Na}_{2} \mathrm{O}$ & 0.21 & 0.22 & 0.19 & 0.17 & 0.06 & 0.30 & 0.30 \\
\hline $\mathrm{P}_{2} \mathrm{O}_{5}$ & $<0.01$ & 0.01 & 0,02 & $<0.01$ & - & - & - \\
\hline $\mathrm{SO}_{3}$ & 35.60 & 21.30 & 21.00 & 21.80 & - & - & - \\
\hline $\mathrm{Cl}^{-}$ & $<0.01$ & $<0.01$ & $<0.01$ & $<0.01$ & - & - & - \\
\hline $\mathrm{BaO}$ & 60.00 & 35.00 & 36.20 & 41.70 & - & - & - \\
\hline $\mathrm{SrO}$ & 0.18 & 0.55 & 0.21 & 0.22 & - & - & - \\
\hline $\mathrm{P}$ & - & - & - & - & 0.025 & 0.50 & 0.60 \\
\hline S & - & - & - & - & 0.01 & 0.03 & 0.03 \\
\hline $\begin{array}{l}\text { Loss by } \\
\text { Annealing }\end{array}$ & 0.92 & 11.70 & 11.40 & 10.50 & - & - & - \\
\hline
\end{tabular}


Table 2 The oxide composition of cementitious materials determined by XRF

\begin{tabular}{|l|l|l|l|l|}
\hline & \multicolumn{4}{|l}{ Chemical composition of cementitious binder materials } \\
\hline Chemical element & Cement CEM I 42.5 R & Slag & Metakaolin & Limestone \\
\hline $\mathrm{SiO}_{2}$ & 19.10 & 37.20 & 53.70 & 99.80 \\
\hline $\mathrm{Al}_{2} \mathrm{O}_{3}$ & 4.43 & 8.50 & 39.90 & \\
\hline $\mathrm{Fe}_{2} \mathrm{O}_{3}$ & 2.60 & 0.24 & 1.15 & 0.05 \\
\hline $\mathrm{CaO}$ & 63.80 & 38.90 & 0.45 & \\
\hline $\mathrm{MgO}$ & 2.39 & 10.20 & 0.30 & \\
\hline $\mathrm{TiO}_{2}$ & 0.25 & 0.30 & 1.42 & - \\
\hline $\mathrm{MnO}$ & 0.19 & 0.51 & $<0.01$ & - \\
\hline $\mathrm{K}_{2} \mathrm{O}$ & 0.53 & 0.36 & 0.74 & - \\
\hline $\mathrm{Na}_{2} \mathrm{O}$ & 0.41 & 0.46 & 0.07 & - \\
\hline $\mathrm{P}_{2} \mathrm{O}_{5}$ & 0.09 & 0.02 & 0.08 & - \\
\hline $\mathrm{SO}$ & & 3.01 & 0.11 & - \\
\hline $\mathrm{Cl}_{3}^{-}$ & 3.49 & 0.03 & $<0.01$ & - \\
\hline $\mathrm{BaO}$ & 0.09 & 0.08 & 0.04 & - \\
\hline $\mathrm{SrO}$ & 0.03 & 0.06 & 0.02 & - \\
\hline $\mathrm{Loss}$ by Annealing & 0.02 & 0.36 & 1.75 & - \\
\hline & 2.31 & & & - \\
\hline
\end{tabular}

Concrete design

For the purpose of this investigation, three kinds of heavyweight concretes with constant dosage of aggregate mix and binder have been designed.

The procedure for preparing concrete samples of HWC is described in [23, 24]. After mixing, the specimens were kept in cubic $(150 \times 150 \times 150 \mathrm{~mm})$ and prism $(100 \times 100 \times 400 \mathrm{~mm})$ molds for $24 \mathrm{~h}$ at room temperature and covered with plastic in order to avoid the drying of samples. After $24 \mathrm{~h}$, the concrete specimens were subjected to standard curing at 7 and 28 days for strength measurements, while shrinkage, bulk density, modulus of dynamic elasticity, and thermophysical properties were determined even after 100 days. 


\section{Results and discussion}

\section{Chemical characteristics of ingredients for concrete manufacture}

Table 1 depicts the oxide composition of aggregate according to the fraction size. Considering the results of aggregates, one can remark that the chemical composition of aggregates changes with grain size. While $\mathrm{Fe}_{2} \mathrm{O}_{3}$ content is much higher in finer fraction, $\mathrm{BaO}$ is found more in a coarser fraction of barite aggregate. Likewise, $\mathrm{Fe}_{3} \mathrm{O}_{4}$ content is higher in finer fraction of magnetite aggregate. Barite concentrate is the finest fraction in which $\mathrm{BaSO}_{4}$ is more accumulated. It serves as filler in concrete. The oxide composition of cement and supplementary cementitious materials listed in Table 2 corresponds to the standard composition of these materials. These oxides are generally bound in mineral phases, so-called clinker minerals or amorphous ones as slag or metakaolin.

Under operating conditions at NPP other than nuclear accidents, the concrete structure is exposed to radiation that can activate some nuclides and also can generate heat inside the materials. Therefore, the knowledge of the isotope concentration in concrete ingredients, hydration heat of binders, mechanical, and thermal properties of concrete is very important in the case of designing and processing of heavyweight concrete as biological shielding. The results of nuclear activation analysis can be summarized as followed.

The isotope composition of CEM I Extra 42.2 R can be characterized as followed: The isotope elements with longer than a month, but less than a yearlong half-life are less than one hundred $\mu \mathrm{g} \mathrm{g}^{-1}$ in the sample. Only the ${ }^{59} \mathrm{Fe}$ with $\mathrm{T}_{1 / 2}=44.5$ days, as major isotope element, was found about 2.13 mass\%. The three important elements with very long-lived nuclides are in small concentration $\left(C \mathrm{~s}=1.16 \mu \mathrm{g} \mathrm{g}^{-1}, C o=11.14 \mu \mathrm{g} \mathrm{g}^{-1}, \mathrm{Eu}=0.39 \mu \mathrm{g} \mathrm{g}^{-1}\right)$.

Five barite samples of different fraction $(0-1,1-2,2-4,4-8,8-16 \mathrm{~mm})$ and one floated barite ore concentrate were analyzed.

Barite is constituted mostly of $\mathrm{Ba}$ and $\mathrm{S}$, but also $\mathrm{Fe}$ and $\mathrm{Mg}$ can be found as major elements. Minor elements as $\mathrm{Si}, \mathrm{Ti}, \mathrm{Al}, \mathrm{Mn}, \mathrm{Na}, \mathrm{K}$, and $\mathrm{Sr}$ were also detected by NAA.

Iron with relatively long half-life $\left(\mathrm{T}_{1 / 2}=44.5 \mathrm{~d}\right)$ is about 20 mass $\%$ in the samples, while minor element isotope $\mathrm{Sb}\left({ }^{124} \mathrm{Sb}-\mathrm{T}_{1 / 2}=60.2 \mathrm{~d}\right)$ is less than $500 \mu \mathrm{g} \mathrm{g}{ }^{-1}$, and $\mathrm{Sc}\left({ }^{46} \mathrm{Sc}-\mathrm{T}_{1 / 2}=83.8 \mathrm{~d}\right)$ is below $2.8 \mu \mathrm{g} \mathrm{g}^{-1}$. Among the very long-life activation products (Cs, Co, Eu), only Co is in considerable amount in the barite samples. The Co content is between 5.4-6 $\mu \mathrm{g} \mathrm{g}^{-1}$ and increases with increasing grain size.

The elemental composition of the floated barite differs from other barite samples, as it has elevated $\mathrm{Ba}, \mathrm{S}$, and $\mathrm{Sr}$ content, but it shows decreased amount of all other isotope elements, especially Cs, $\mathrm{Co}$, and $\mathrm{Eu}$, as trace elements with concentration below the detection limit of NAA, while the Fe content is just around 1 mass\%.

Five magnetite samples of different fraction $(0-1,1-2,2-4,4-8,8-16 \mathrm{~mm})$ were analyzed considering mainly $\mathrm{Fe}_{3} \mathrm{O}_{4}$. As it has expected, their major element is $\mathrm{Fe}$ with concentration varying between 65 and 69 mass\%. From the view of activation properties, the most significant element is 
Fe in these samples. Concentration of Ce (less than $\left.50 \mu \mathrm{g} \mathrm{g}^{-1}\right), \mathrm{Cr}\left(<20 \mu \mathrm{g} \mathrm{g}^{-1}\right)$, and $\mathrm{Sc}\left(<8 \mu \mathrm{g} \mathrm{g}^{-1}\right)$ is not significant. Cs is under the detection limit, while $\mathrm{Eu}$ is less than $1 \mu \mathrm{g} \mathrm{g}^{-1}$. Co concentration in magnetite samples varied from 99 to $127 \mu \mathrm{g} \mathrm{g}^{-1}$ according to particle size.

Metakaolin (MK) is constituted mostly of $\mathrm{Si}$ and $\mathrm{Al}$ which are in perspective of irradiation considered as neutral elements. The very long-lived nuclides $\mathrm{Cs}, \mathrm{Co}$, and $\mathrm{Eu}$ in $\mathrm{MK}$ were of concentration $15 \mu \mathrm{g} \mathrm{g}^{-1}, 22 \mu \mathrm{g} \mathrm{g}^{-1}$, and $2.5 \mu \mathrm{g} \mathrm{g}^{-1}$, respectively.

The major elements in blast furnace slag (BFS) are, next to $\mathrm{Si}$ and $\mathrm{Al}, \mathrm{Ca}$ and $\mathrm{Mg}$ with low activation properties. The long-life isotope Eu content is about $1.53 \mu \mathrm{g} \mathrm{g}^{-1}$. This value is about five times higher compared with that of cement. Minor elements, like Ti, Fe, Mn, Na, K, and S, and trace elements like H, B, Cl, Sm, Gd, Ba, Ce, Cr, Eu, Hf, La, Nd, Sc, Sm, Sr, Ta, Tb, Th, U, $\mathrm{Yb}$ have been measured in BFS. The $\mathrm{Cr}, \mathrm{Fe}, \mathrm{Sr}, \mathrm{Ta}$, and also $\mathrm{Cs}$ and $\mathrm{Co}$ are in low concentration compared to those found in cement. Th, $\mathrm{Ce}, \mathrm{Hf}, \mathrm{Sr}, \mathrm{Tb}$, and $\mathrm{Sc}$ content in BFS is higher than measured in the cement sample.

Characteristics of physical properties of used materials

Density of aggregate in individual particle size, bulk density of aggregates, and specific surface were determined by different methods (pycnometry, Blaine) and reported in Table 3.

Table 3 Physical characteristics of used materials

\begin{tabular}{|c|c|c|c|c|}
\hline Materials & Fraction/mm & $\begin{array}{l}\text { Blaine specific } \\
\text { surface } / \mathrm{cm}^{2} \mathrm{~g}^{-1}\end{array}$ & $\begin{array}{l}\text { Pycnometry } \\
\text { density } \rho / k^{-3} ~ m^{-3}\end{array}$ & $\begin{array}{l}\text { Bulk } \\
\text { density } \rho / \mathrm{kg} \mathrm{m}^{-3}\end{array}$ \\
\hline \multirow[t]{3}{*}{ BA } & Barite 0/4 & \multirow[t]{3}{*}{$230 \sim 310$} & 4113 & \multirow[t]{4}{*}{3845} \\
\hline & Barite 4/8 & & 4049 & \\
\hline & Barite 8/16 & & 4076 & \\
\hline \multicolumn{2}{|c|}{ Barite concentrate } & 1076 & 4491 & \\
\hline \multirow[t]{3}{*}{ MAG } & Magnetite $0 / 2$ & \multirow[t]{3}{*}{$180 \sim 230$} & 5118 & \multirow[t]{3}{*}{4761} \\
\hline & Magnetite $0 / 8$ & & 4948 & \\
\hline & Magnetite 0/20 & & 4973 & \\
\hline \multicolumn{2}{|c|}{ Mix BA/MAG } & & & 4100 \\
\hline \multicolumn{2}{|l|}{ CEM } & 4341 & 3143 & \\
\hline \multicolumn{2}{|l|}{ BFS } & 4275 & 2904 & \\
\hline \multicolumn{2}{|l|}{ MK } & 2586 & 2627 & \\
\hline \multicolumn{2}{|l|}{ SP } & & 1065 & \\
\hline \multicolumn{2}{|l|}{ W } & & 1000 & \\
\hline
\end{tabular}


While the density of barite varies negligibly with fraction size, that of magnetite depends strongly on the particle size. Considering the chemical composition of these aggregates listed in Table 1, it is evident that the content of $\mathrm{BaO}$ and $\mathrm{Fe}_{2} \mathrm{O}_{3}$ is responsible for these changes. While the low content of $\mathrm{BaO}$ in fine fraction of barite aggregate is compensated by a high content of $\mathrm{Fe}_{2} \mathrm{O}_{3}$ in this fraction, in magnetite aggregate the decrease of $\mathrm{Fe}_{3} \mathrm{O}_{4}$ is not balanced by any oxide. That is why the density of magnetite strongly varies with particle size.

Assessment of hydration heat using calorimeter

Hydration of five samples (Table 4) was evaluated by conduction calorimetry under isothermal conditions during 2 days.

\section{Table 4 Composition of blend cements}

\begin{tabular}{|l|l|l|l|l|l|}
\hline & CEM & BSF & MK & SF & LL \\
\hline CEM I 42.5 R [23] & 100 & - & - & - & - \\
\hline CEM_75_A [23] & 75 & 15 & 5 & 5 & - \\
\hline CEM_75_B & 75 & 15 & 5 & - & 5 \\
\hline CEM_65_A & 65 & 20 & 5 & - & 10 \\
\hline CEM_55_A & 55 & 25 & 5 & - & 15 \\
\hline
\end{tabular}

Heat flow and cumulative heat are shown in Figs. 2,3, respectively. The heat flow of CEM I 42.5 $\mathrm{R}$ and CEM_75_A is faster and with cumulative heat exceeding $250 \mathrm{j} \mathrm{g}^{-1}$ after 2 days. They were previously used in the preparation of high strength heavyweight concretes [23]. But, some cracks were observed on the surface of samples due to the thermal stress of shrinkage caused by high hydration heat. Then, a new series of samples comprising limestone instead of silica fume is prepared through the present work. Hydration reaction, expressed by peak position and peak intensity, is substantially retarded. 
Fig. 2 Heat flow of binder samples

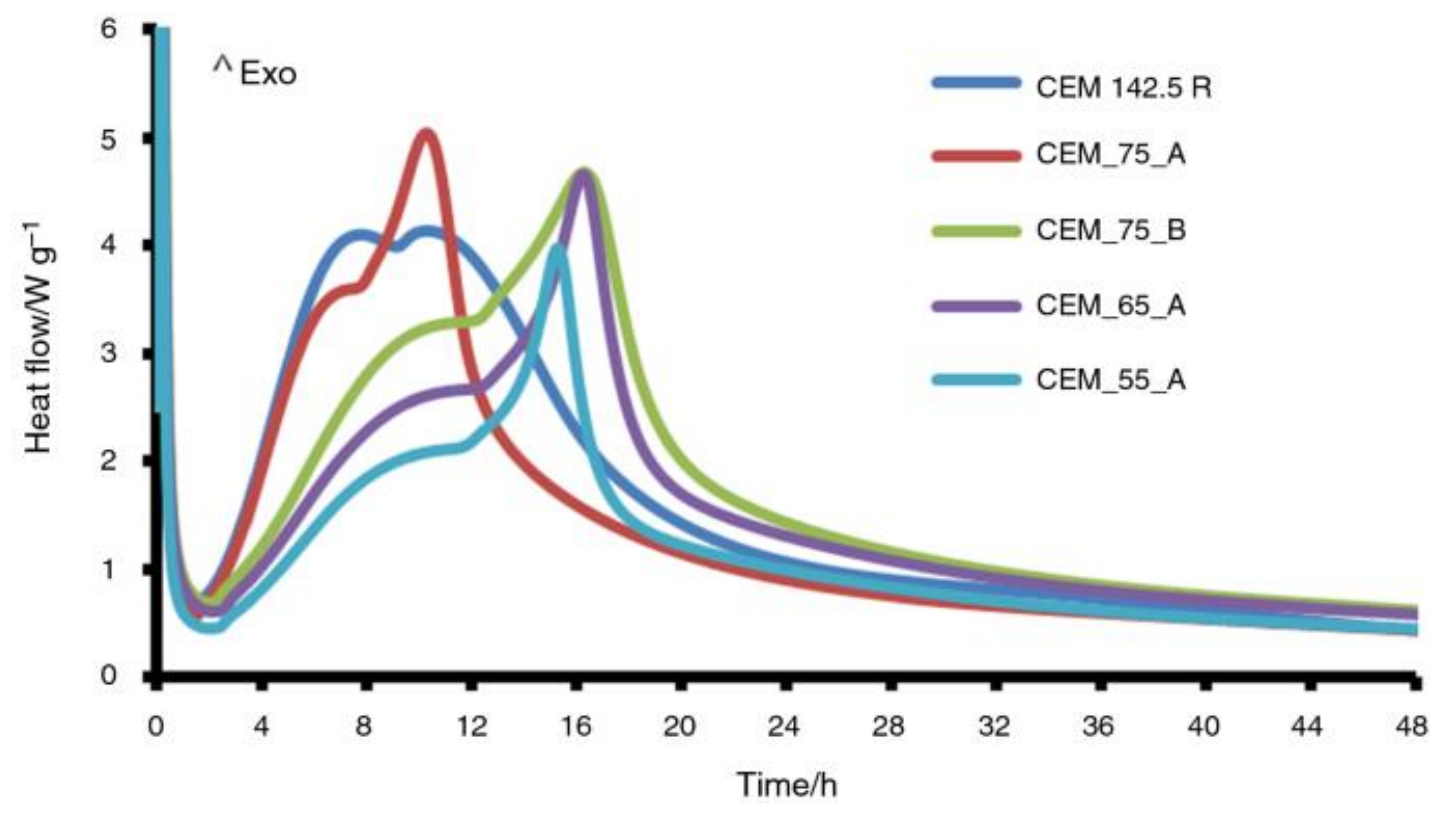

Fig. 3 Cumulative heat of binder samples

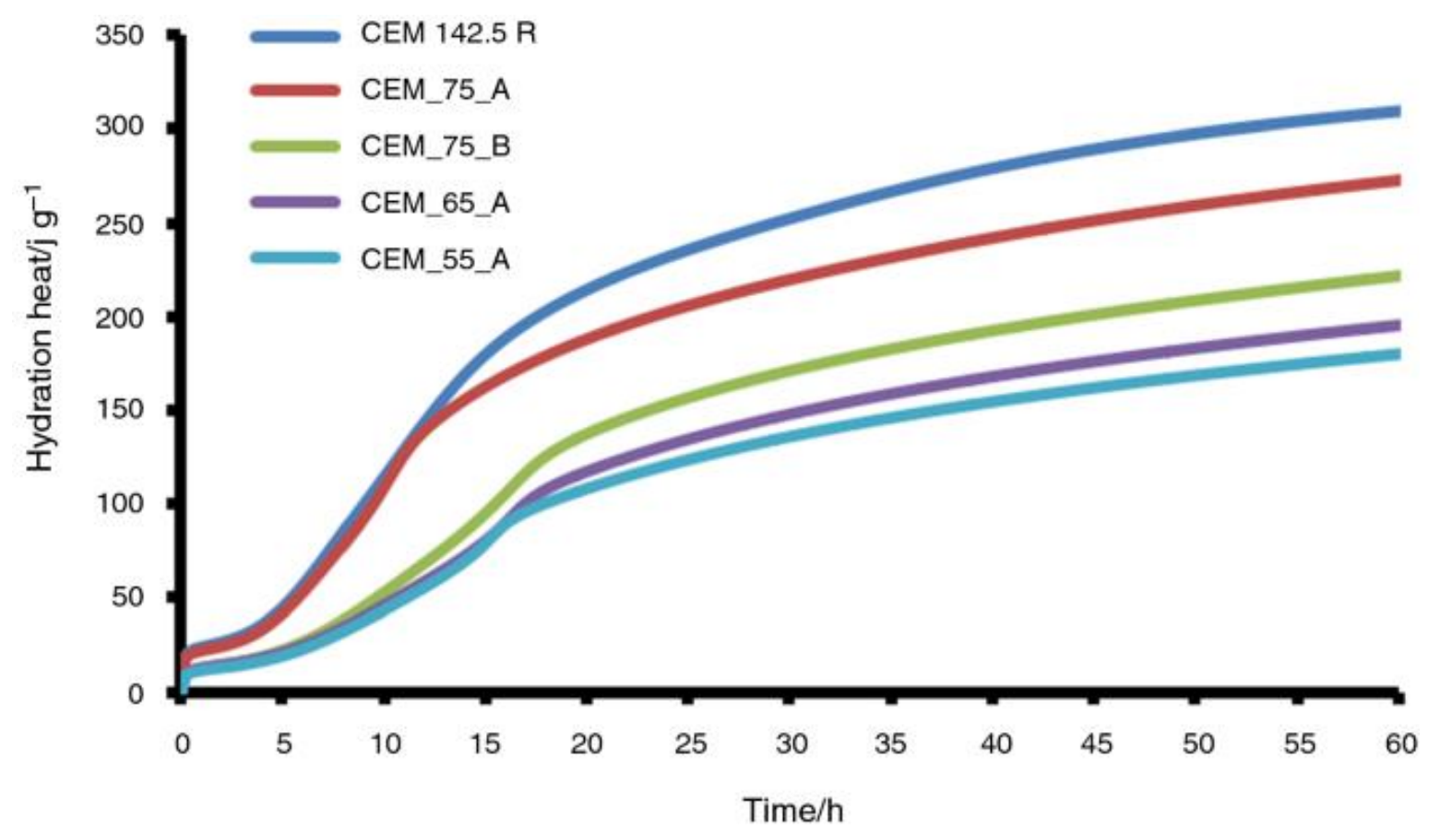


From the results of cumulative heat reported in Fig. 3, CEM I 42.5 R and CEM_75_A display higher rate of generated heat from hydration than that of CEM_75_B, CEM_65_A, and CEM_55_A. The main difference is the presence of limestone. Keeping into consideration the interpretation of calorimetric curves [9], it is clear that the use of supplementary cementitious materials has effectively mitigated the hydration heat. The peak characterizing $\mathrm{C}_{3} \mathrm{~S}$ hydration is reduced in intensity due to the dilution effect, but the $\mathrm{C}_{3} \mathrm{~A}$ peaks are intensified and hydration reaction for all samples is retarded. To avoid the cracking due to the hydration heat, binders CEM_75_B, CEM_65_A, and CEM_55_A were used to prepare concretes denoted HWC1, HWC2, and HWC3, respectively as reported in Table 5.

\section{Table 5 Composition of concretes}

\begin{tabular}{|l|l|l|l|}
\hline \multicolumn{2}{|l}{ Concrete mixtures per $\mathbf{1} \mathbf{~ m}^{\mathbf{3}} / \mathbf{m a s s} \%$} & HWC2 & HWC3 \\
\hline & HWC1 & 53.3 & 53.3 \\
\hline BA & 53.3 & 28.7 & 28.7 \\
\hline MAG & 28.7 & 7 & 6 \\
\hline CEM & 8 & 2.5 & 3 \\
\hline BFS & 2 & 1.5 & 2 \\
\hline LL & 1 & 1 & 1 \\
\hline MK & 1 & 0.10 & 0.13 \\
\hline SP & $0.6 \mathrm{~kg}$ per $100 \mathrm{~kg}$ & 5.18 & 6 \\
\hline W & 6 & & \\
\hline
\end{tabular}

\section{Mechanical properties of HWC}

The compressive strength of the concrete was carried out by three variants of the compressive strength tests: (1) compressive strength on cubic samples with dimensions $150 \times 150 \times 150 \mathrm{~mm}$ $\left(F_{\text {c-cubic }}\right),(2)$ compressive strength on prismatic samples with dimensions $100 \times 100 \times 400 \mathrm{~mm}\left(F_{\mathrm{c}-}\right.$ prism), and (3) compressive strength in lateral pressure on the fractions of prisms by using a top and bottom steel washer with dimensions $100 \times 100 \times 100 \mathrm{~mm}\left(F_{\mathrm{c}-\mathrm{lp}}\right)$.

Table $\underline{6}$ summarizes the results of the measured mechanical characteristics of heavyweight concretes. The tests were done on three samples in each category (cube, prism, and lateral) at 7and 28-day mature. 


\section{Table 6 The measured compressive and tensile strength of the concrete and}

elastic modulus

\begin{tabular}{|c|c|c|c|c|c|c|}
\hline & \multicolumn{2}{|l|}{ HWC1 } & \multicolumn{2}{|l|}{ HWC2 } & \multicolumn{2}{|l|}{ HWC3 } \\
\hline & $\begin{array}{l}\text { 7-day } \\
\text { concrete }\end{array}$ & $\begin{array}{l}\text { 28-day } \\
\text { concrete }\end{array}$ & $\begin{array}{l}\text { 7-day } \\
\text { concrete }\end{array}$ & $\begin{array}{l}\text { 28-day } \\
\text { concrete }\end{array}$ & $\begin{array}{l}\text { 7-day } \\
\text { concrete }\end{array}$ & $\begin{array}{l}\text { 28-day } \\
\text { concrete }\end{array}$ \\
\hline$f_{\mathrm{c}, \text { cube }} / \mathrm{N} \mathrm{mm}^{-2}$ & $44.22 \pm 1.02$ & $49.78 \pm 1.18$ & $39.56 \pm 1.18$ & $49.23 \pm 1.10$ & $37.41 \pm 1.10$ & $46.15 \pm 3.03$ \\
\hline$f_{\mathrm{c}, \text { prism }} / \mathrm{N} \mathrm{mm}^{-2}$ & $36.63 \pm 2.56$ & $47.75 \pm 1.94$ & $35.95 \pm 1.72$ & $47.25 \pm 0.96$ & $30.00 \pm 2.35$ & $39.88 \pm 3.20$ \\
\hline$f_{\mathrm{lp}, \text { lateral }} / \mathrm{N} \mathrm{mm}^{-2}$ & $40.82 \pm 1.63$ & $50.00 \pm 3.87$ & $41.83 \pm 1.21$ & $51.08 \pm 1.93$ & $36.50 \pm 2.10$ & $44.83 \pm 2.14$ \\
\hline Tensile strength $/ \mathrm{N} \mathrm{mm}^{-2}$ & $7.35 \pm 0.52$ & $7.68 \pm 0.86$ & $6.41 \pm 0.09$ & $7.08 \pm 0.30$ & $6.54 \pm 0.68$ & $7.49 \pm 0.21$ \\
\hline $\begin{array}{l}\text { Static modulus of } \\
\text { elasticity/GPa }\end{array}$ & $29.45 \pm 1.23$ & $30.93 \pm 1.20$ & $30.53 \pm 1.19$ & $31.80 \pm 0.26$ & $30.96 \pm 1.13$ & $32.68 \pm 1.14$ \\
\hline
\end{tabular}

$f_{\mathrm{c}}$, cube is compressive strength on cubic sample, $f_{1}$, lateral is compressive strength on lateral, and $f_{\mathrm{p}, \text { prism }}$ is compressive strength on prism sample.

Taking the experimental results listed in Table 6 into account, one can remark that tensile strength and static modulus of elasticity vary slightly with concrete type and curing time. According to the standard EuroCode 2 [25], the modulus of elasticity of concrete is the resultant of elasticity moduli of its components and concrete elastic deformations and depends to great extent on its composition, namely on aggregates. The content of aggregate is the same in all HWC; therefore, static modulus of elasticity is nearly the same. The compressive strengths increase with increasing time and are influenced by binder compositions. HWC3 with the lowest cement content and the highest SCMs

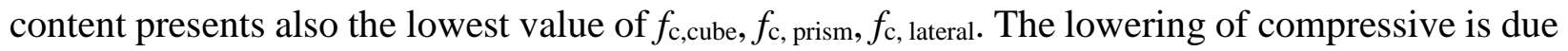
to the pronounced dilution effect (55\% cement). Also, the ratios cement/BFS and cement/MK constitute an important factor for the effective pozzolanic reaction which generates additional hydrated products. Basing on results of compressive strength on cubic samples, all HWC can be considered belonging, at least to strength class C35/45.

\section{$\underline{\text { Pore structure analysis }}$}

After 28 days of mature, hardened cement paste from the concrete matrices was carefully extracted and analyzed by MIP to establish a correlation between mechanical properties and pore structure. While a linear relationship between HWC composition, mechanical properties, and total porosity cannot easily be expressed, the best agreement is found by considering parameters such interparticle porosity (spaces between particles), intraparticle porosity (within particles), median pore radius, and total surface area reported in Table 7 . These four parameters therefore provide the relevant information regarding the performance of concrete. 
Table 7 Pore characteristics of HWC samples

\begin{tabular}{|c|c|c|c|c|c|}
\hline & \multicolumn{2}{|c|}{ Total porosity/\% } & \multirow{2}{*}{$\begin{array}{l}\text { Median }(50 \% \text { intruded }) \\
\text { pore radius/nm }\end{array}$} & \multirow{2}{*}{$\begin{array}{l}\text { Total surface } \\
\text { area/ } / \mathbf{m}^{2} \mathbf{g}\end{array}$} & \multirow{2}{*}{$\begin{array}{l}\text { Total } \\
\text { Porosity } \\
\%\end{array}$} \\
\hline & $\begin{array}{l}\text { Interparticle } \\
\text { porosity }\end{array}$ & $\begin{array}{l}\text { Intraparticle } \\
\text { porosity }\end{array}$ & & & \\
\hline HWC1 & 3.04 & 10.84 & 743.58 & 1.72 & 13.89 \\
\hline HWC2 & 0.94 & 10.99 & 587.78 & 1.78 & 11.93 \\
\hline HWC3 & 0.71 & 15.17 & 555.58 & 2.42 & 15.88 \\
\hline
\end{tabular}

The sum of interparticle porosity and intraparticle porosity forms the total porosity. These pore parameters result from the following equations [26]:

$$
\begin{gathered}
\text { Interparticle porosity (\%) }=100 \frac{V_{v}}{V_{b}} \\
\text { Intraparticle porosity (\%) }=100 \frac{V_{t}-V_{v}}{V_{b}} \\
\text { Mercury intrusion (total)porosity (\%) }=100 \frac{V_{t}}{V_{b}}
\end{gathered}
$$

where $V_{\mathrm{b}}$ is the bulk volume of the sample, $V_{\mathrm{v}}$ is the volume of mercury intruded up to the interparticle filling limit, and $V_{\mathrm{t}}$ is the total volume of mercury intruded up to the maximum pressure.

It can be remarked that interparticle porosity (spaces between particles) decreases with increasing content of SCMs. Indeed, SCMs (BFS, MK, and LL) act as fillers fulfilling the space between larger particles (cement grains). The decrease in interparticle porosity has not affected positively the compressive strength. Contrary to interparticle, the intraparticle porosity (within particles) increases with increasing content of SCMs. With reducing content of Portland cement which hydration contributes substantially to the formation of binders with gel $(<10 \mathrm{~nm})$, capillary and micro pores $(10 \mathrm{~nm} \sim 10000 \mathrm{~nm}$ ), it is evident that up to 28 days the pozzolanic effect has not yet overcome the dilution effect. Median pore radius and total surface area express a linear relationship with mechanical properties and HWC composition. While median pore radius decreases with increasing SCMs content, total surface area of pores increases with cement replacement level. A significant decrease of mechanical properties is observed with HWC3, in which the content of cement is $55 \%$.

The density of fresh concrete and hardened one after 7 and 28 days is listed in Table $\underline{8}$. The bulk density varies from 3400 to $3600 \mathrm{~kg} \mathrm{~m}^{-3}$. The density of fresh concrete is higher than that of the hardened one. Hydration and desiccation process could be the main reasons, as a part of the water 
is consumed to form hydration products in the concrete and part of it evaporated, then the bulk density decreases.

\section{Table 8 Bulk density in $\mathrm{kgm}^{-3}$}

\begin{tabular}{|l|l|l|l|}
\hline & Fresh concrete & 7-day concrete & 28-day concrete \\
\hline HWC1 & 3510 & 3450 & 3430 \\
\hline HWC2 & 3510 & 3490 & 3490 \\
\hline HWC3 & 3560 & 3490 & 3500 \\
\hline
\end{tabular}

It is evident that these concretes belong to the class of heavyweight concrete with a bulk density exceeding $3400 \mathrm{~kg} \mathrm{~m}^{-3}$.

$\underline{\text { Shrinkage characteristics }}$

The typical shrinkage strain behavior of the three HWC is plotted in Fig. $\underline{4}$. Samples underwent volume changes as a result of physical and chemical interaction with internal and external environment. In all concrete specimens, expansion or swelling is observed at the initial stage (during the first $4 \mathrm{~h}$ ) as demonstrated by decreasing of shrinkage strain rate. Kovler [27] has noted that initial swelling, followed by shrinkage of the fresh concrete occurs over the first stages of hydration, a few hours following mixing and casting. This trend of longitudinal change is generally observed with ordinary concrete that undergo expansion during the plastic stage and depends on many parameters, such as water to cement ratio, fineness of the cement, drying conditions, temperature, and others [28]. It is worth noting that the concrete composition significantly affects the magnitude of concrete shrinkage because the flux of moisture in the pore structure of concrete is mainly related to the restraining effect of the amount and type of aggregates.

Fig. 4 Shrinkage of HWC over time

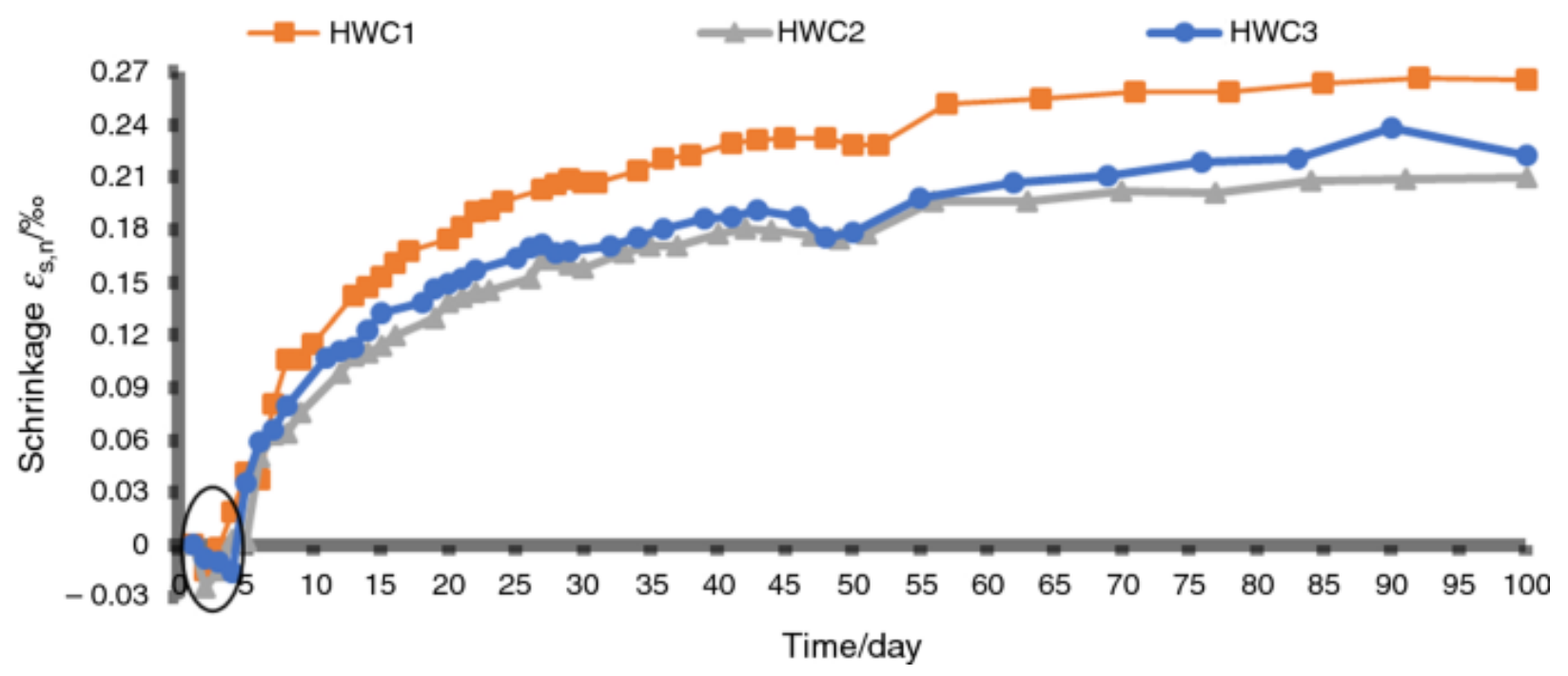


Along with the determination of shrinkage characteristics, bulk density and dynamic modulus of elasticity of samples were determined. The results are reported in Figs. 5, 6. It appears clearly that the bulk density decreases during the same period corresponding to the swelling of concrete samples. After a period of decreasing, bulk density increased slightly with time and showed no significant difference.

Fig. 5 Bulk density over time

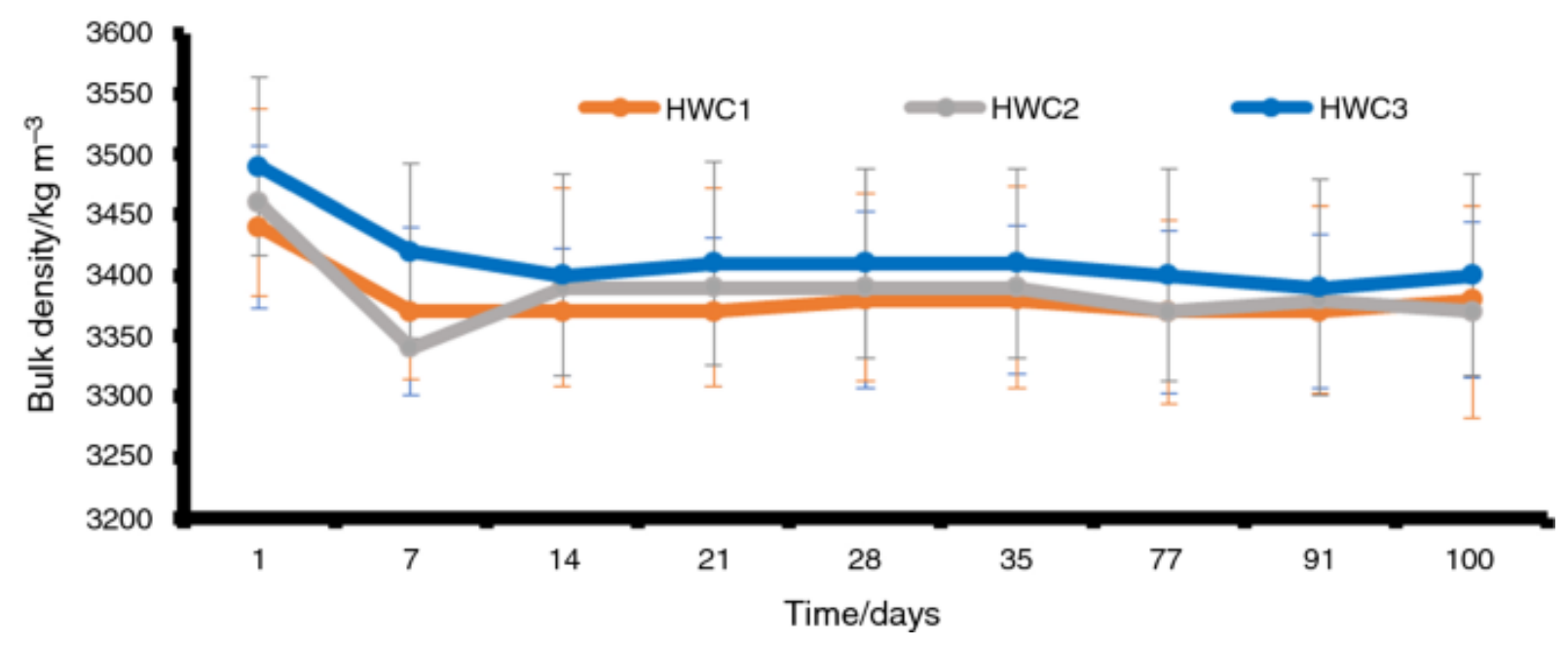

Fig. 6 Development of dynamic modulus of elasticity over time

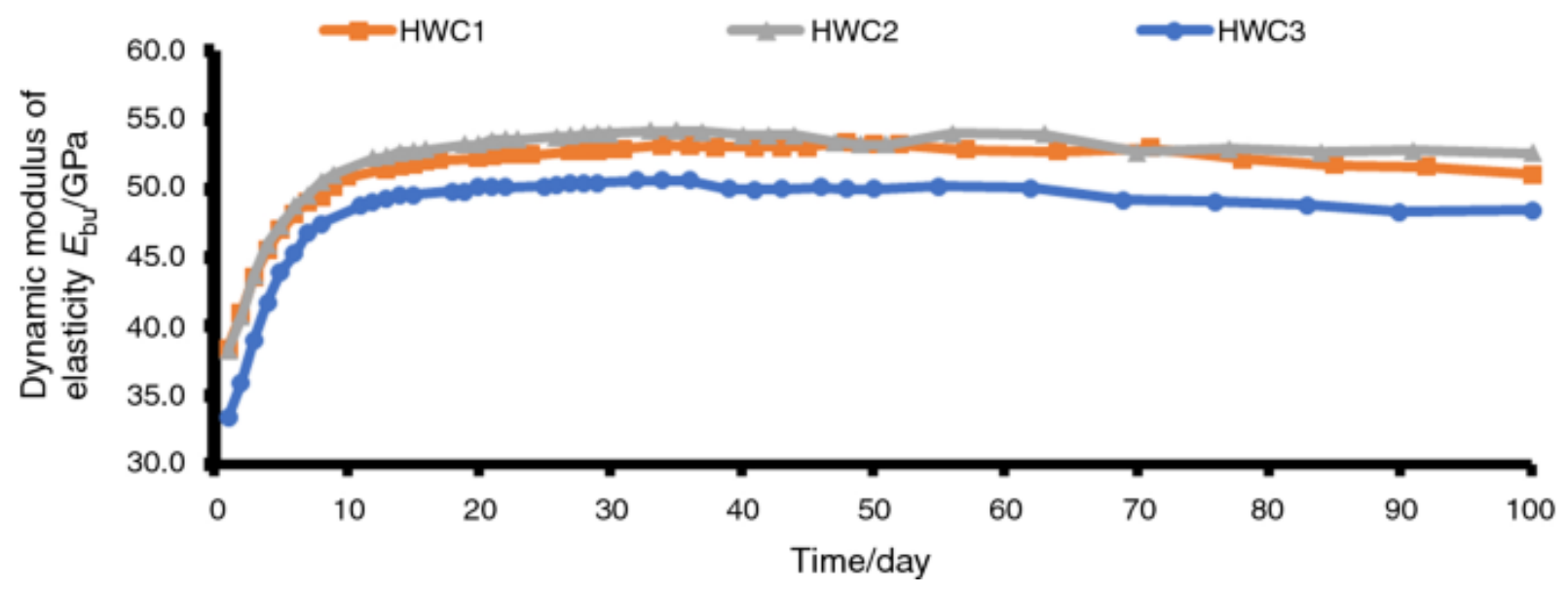

In the time of the plastic concrete, dynamic modulus of elasticity increased significantly to reach a steady stage after hardening.

Thermal properties

The thermal properties (thermal conductivity, volumetric heat capacity, and thermal diffusivity) of the concretes are represented by curves depicted at Figs. 7-9. 
Fig. 7 Thermal conductivity of HWC over time

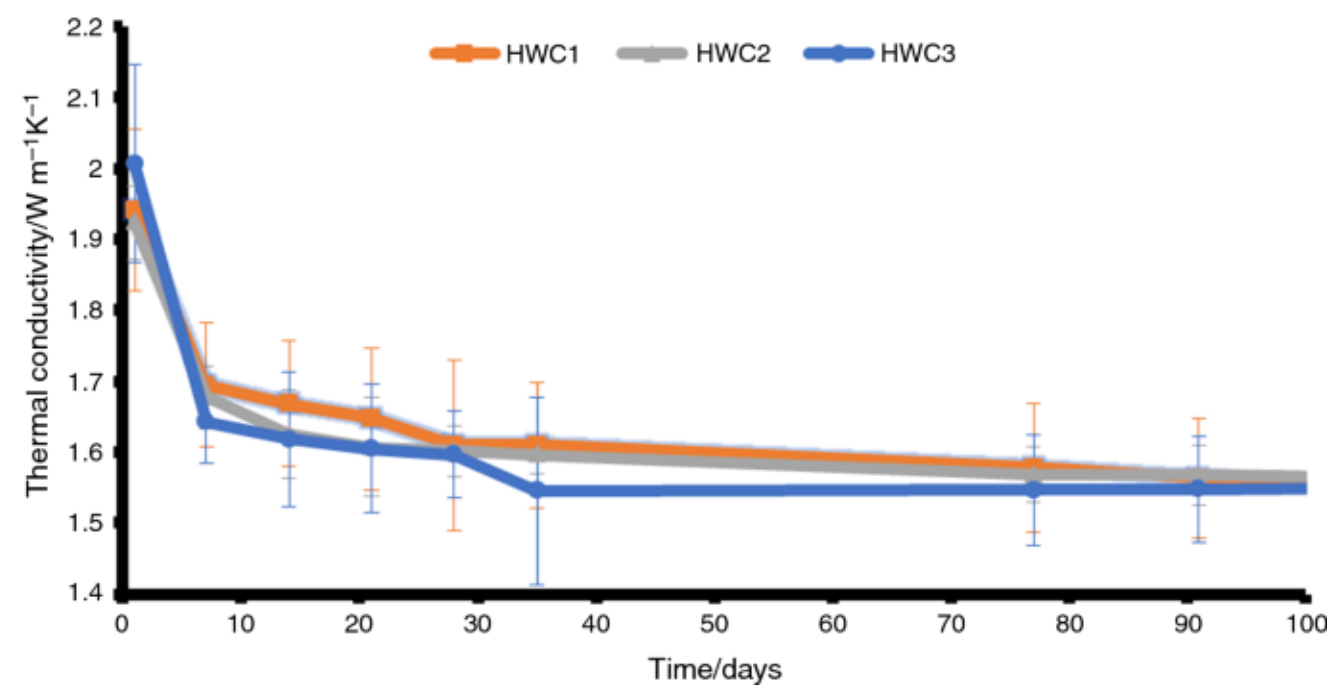

Fig. 8 Volumetric heat capacity over time

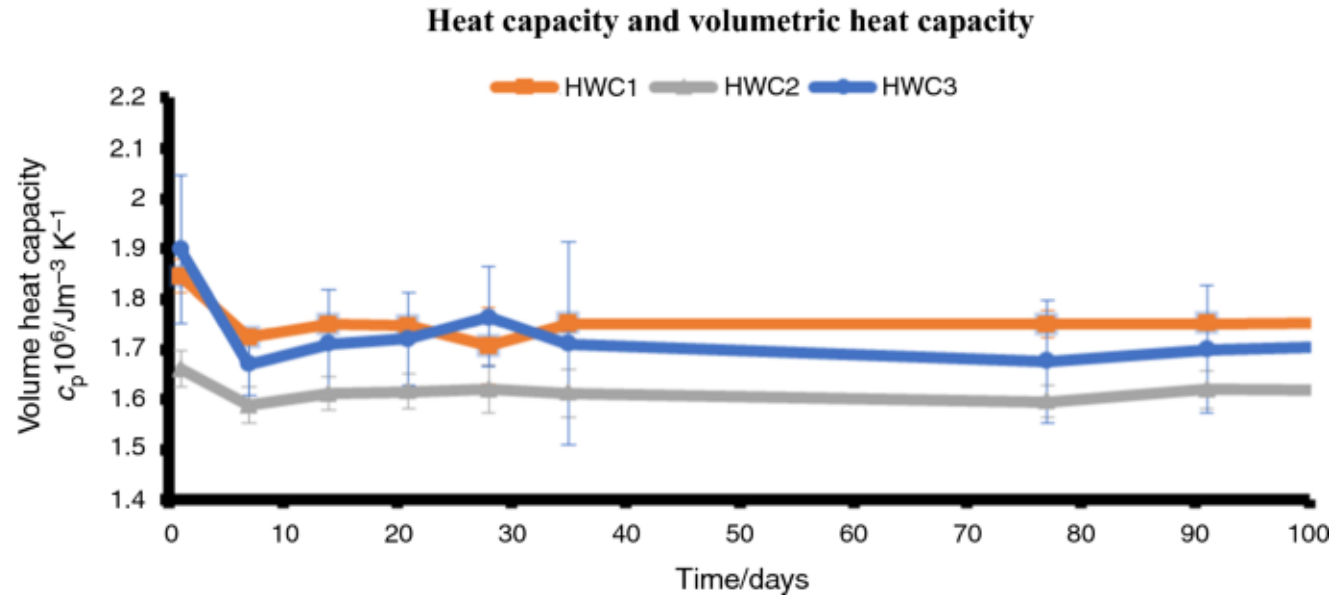

Fig. 9 Change of thermal diffusivity over time

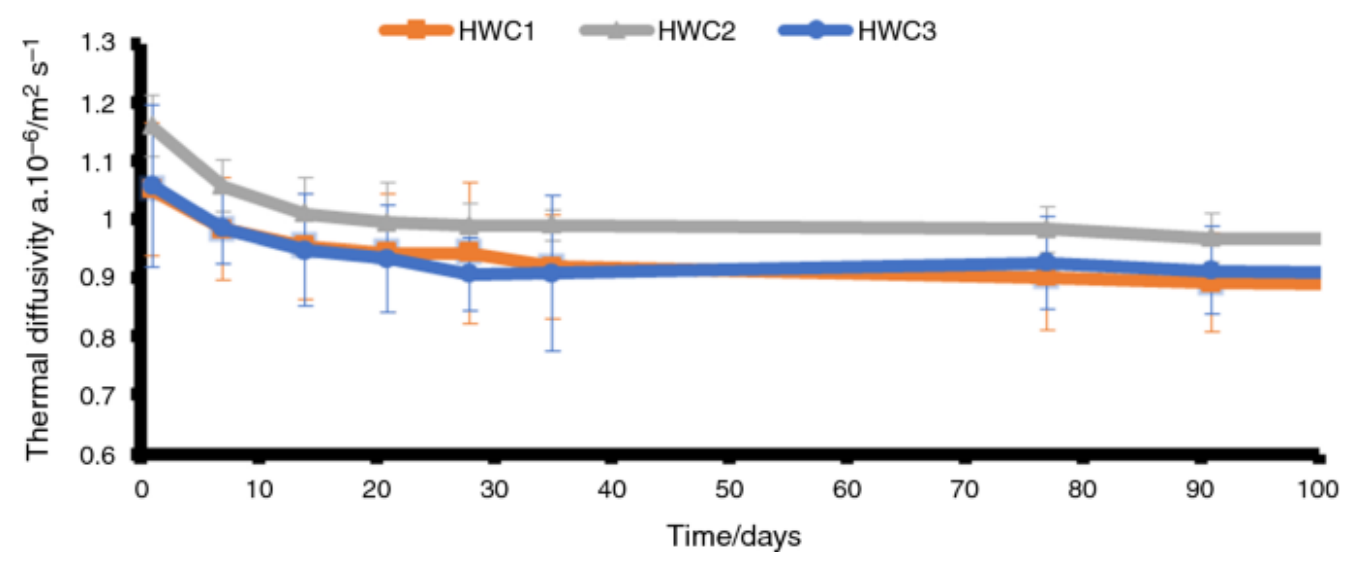




\section{Thermal conductivity}

The influence of aggregates is the same in all concrete samples, as they contain the same amount of fillers. Therefore, the thermal properties are mostly depending on aggregate content which represents $80 \%$ of concrete. The main difference is in binder content which represents only $18 \%$ of concrete. Thermal conductivity decreases till the period of 35 days; therefore, the dependence of conductivity on moisture content should be taken in consideration as reported in $[28,29,30]$. It is clear that thermal conductivity slightly depends on limestone content.

\section{Heat capacity and volumetric heat capacity}

For mass concrete applications as biological shielding in nuclear power plant, thermal performance is necessary to characterize in terms of thermal diffusivity [16]. Concrete with a high thermal diffusivity will rapidly adjust its temperature to match that of its surroundings. Therefore, a low thermal diffusivity is preferred so that the concrete may act as a heat barrier to stop temperature extremes experienced during a diurnal cycle.

The specific heat of the material is defined as its ability to store heat, whereas the thermal diffusivity combines the transmission and storage properties of the material and is indicative of the rate of change of temperature within the material. It is defined by Eq. 4 as the ratio between thermal conductivity and volumetric heat.

The calculated values of thermal conductivity and volumetric heat capacity were used to determine thermal diffusivity (Fig. 9).

The thermal diffusivity values decrease slightly during the period where bulk density and thermal conductivity also decrease. It characterizes the thermal properties of concrete during the hydrating phase where mechanical properties significantly increase. During this period, relative humidity inside the samples could be higher, hence the statement formulated by [29] that water has higher diffusivity compared with aggregates and cement.

In summary, for the thermal mass materials such as massive structure, each component confined in $1 \mathrm{~m}^{3}$ with determined mass (density) play important role in the characterization of thermal properties. Indeed, the effect of density on the thermal diffusivity is significant and shows that the thermal diffusivity and bulk density of concrete values are inversely proportional.

The values of thermal conductivity, volumetric heat capacity, and thermal diffusivity are in agreement with $[14,16]$ using magnetite powder or magnetite aggregate.

At normal conditions, concrete has a low thermal mass diffusivity, which means it slows the heat transfer through the material; stores a large amount of heat; and is less sensitive to temperature differences in the surrounding environment. 


\section{Conclusions}

Preliminary reports on concrete with the potentiality to be used as biological shielding in nuclear power plant are presented in this paper. Concretes have been prepared using low hydration heat cementitious materials and a mix of two aggregates.

Binders composed of CEM I 42.5 R and combination with supplementary cementitious materials can be considered as low-heat cement with low $\mathrm{C}_{3} \mathrm{~A}$ content suitable for the preparation of massive concrete.

The isotope concentration in concrete determined by neutron activation analysis is convenient for the fabrication of heavyweight concrete as biological shielding with the possibility to be exposed to gamma and neutron radiation.

The results clearly demonstrated that all samples are heavyweight concretes with a bulk density exceeding $3400 \mathrm{~kg} \mathrm{~m}^{-3}$.

Concrete exhibited relative high compressive strength suitable as structural materials.

Though a common phenomenon of swelling during the plastic stage was observed at earlier curing period, HWC samples have presented excellent volume stability.

Thermal properties were determined and were found in good agreement with those reported in the literature.

\section{References}

1. Ouda AS. Development of high-performance heavy density concrete using different aggregates for Gamma-Ray shielding. Prog Nucl Energy. 2015;79:4855. https://doi.org/10.1016/j.pnucene.2014.11.009.

2. Mostofinejad D, Reisi M, Shirani A. Mix design effective parameters on gamma-ray attenuation coefficient and strength of normal and heavyweight concrete. Constr Build Mater. 2012;28:224-9. https://doi.org/10.1016/j.conbuildmat.2011.08.043.

3. İlker Bekir Topçu. Properties of heavyweight concrete produced with barite. Cem Concr Res. 2003;33:815-22. https://doi.org/10.1016/S0008-8846(02)01063-3.

4. Kilincarslan S, Akkurt I, Basyigit C. The effect of barite rate on some physical and mechanical properties of concrete. Mater Sci Eng A. 2006;424:836. https://doi.org/10.1016/j.msea.2006.02.033.

5. Khalaf MA, Ban CC, Ramli M. The constituents, properties and application of heavyweight concrete: a review. Constr Build Mater. 2019;215:7389. https://doi.org/10.1016/j.conbuildmat.2019.04.146.

6. Huang Y, Liu G, Huang S, Rao R, Hu C. Experimental and finite element investigations on the temperature field of a massive bridge pier caused by the hydration heat of concrete. Constr Build Mater.

2018;192:240-

52. https://doi.org/10.1016/j.conbuildmat.2018.10.128. 
7. Xu Q, Ruiz JM, Hu J, Wang K, Rasmussen RO. Modeling hydration properties and temperature developments of early-age concrete pavement using calorimetry tests. Thermochim Acta. 2011;512(1-2):76-85. https://doi.org/10.1016/j.tca.2010.09.003.

8. Chu I, Kwon SH, Amin MN, Kim JK. Estimation of temperature effects on autogenous shrinkage of concrete by a new prediction model. Constr Build Mater. 2012;35:17182. https://doi.org/10.1016/j.conbuildmat.2012.03.005.

9. Duan Y, Zhang C, Chang X. Mesoscopic numerical simulation of temperature crack with non-uniform temperature distribution in concrete. Appl Mech Mater. 2014;477-478:10148. https://doi.org/10.4028/www.scientific.net/AMM.477-478.1014.

10. Palou MT, Kuzielova E, Novotny R, Šoukal F, Žemlička M. Blended cements consisting of Portland cement-slag-silica fume-metakaolin system. J Therm Anal Calorim. 2016;125:1025-34. https://doi.org/10.1007/s10973-016-5399-5.

11. Palou MT, Kuzielova E, Žemlička M, Novotny R, Másilko J. The effect of metakaolin upon the formation of ettringite in metakaolin-lime-gypsum ternary systems. J Therm Anal Calorim. 2018;133:77-86. https://doi.org/10.1007/s10973-017-6885-0.

12. Kuzielova E, Žemlička M, Novotny R, Palou MT. Simultaneous effect of silica fume, metakaolin and ground granulated blast-furnace slag on the hydration of multicomponent cementitious binders. J Therm Anal Calorim. 2019;136:152737. https://doi.org/10.1007/s10973-018-7813-7.

13. Park K, Kim HT, Kwon TH, Choi E. Effect of neutron irradiation on response of reinforced concrete members for nuclear power plants. Nucl Eng Des. 2016;310:1526. https://doi.org/10.1016/j.nucengdes.2016.09.034.

14. Sikora P, Elrahman MA, Horszczaruk E, Brzozowski P, Stephan D. Incorporation of magnetite powder as a cement additive for improving thermal resistance and gamma-ray shielding properties of cement-based Composites. Constr Build Mater. 2019;204:11321. https://doi.org/10.1016/j.conbuildmat.2019.01.161.

15. Jaskulski R, Glinicki MA, Kubissa W, Dabrowski M. Application of a non-stationary method in determination of the thermal properties of radiation shielding concrete with heavy and hydrous aggregate. Int $\mathrm{J}$ Heat Mass Trans. 2019;130:88292. https://doi.org/10.1016/j.ijheatmasstransfer.2018.07.050.

16. Lee H-S, Kwon S-J. Effects of magnetite aggregate and steel powder on thermal conductivity and porosity in concrete for nuclear power plant, Research Article. Adv Mater Sci Eng. 2016;9526251:8. https://doi.org/10.1155/2016/9526251.

17. Krishnaiah S, Singh DN. Determination of thermal properties of some supplementary cementing materials used in cement and concrete. Constr Build Mater. 2006;20:1938. https://doi.org/10.1016/j.conbuildmat.2004.10.001.

18. Zhang W, Min H, Gu X, Xi Y, Xing Y. Mesoscale model for thermal conductivity of concrete. Constr Build Mater. 2015;98:816. https://doi.org/10.1016/j.conbuildmat.2015.08.106.

19. Asadi I, Shafigh P, Abu Hassan ZFB, Mahyuddin NB. Thermal conductivity of concretea review. J Build Eng. 2018;1:2. https://doi.org/10.1016/j.jobe.2018.07.002. 
20. Demirboga R, Turkmen I, Karakoc MB. Thermo-mechanical properties of concrete containing high-volume mineral admixtures. Build Environ. 2007;42:34954. https://doi.org/10.1016/j.buildenv.2005.08.027.

21. Demirboga R. Influence of mineral admixtures on thermal conductivity and compressive strength of mortar. Energy Build. 2003;35:189-92. https://doi.org/10.1016/S03787788(02)00052-X.

22. Szentmiklósi L, Párkányi D, Sziklai-László I. Upgrade of the Budapest neutron activation analysis laboratory. J Radioanal Nucl Chem. 2016;309:919. https://doi.org/10.1007/s10967-016-4776-7.

23. Dragomirová J, Palou M. Development of high-compressive heavyweight concrete based on Portland cement and supplementary cementitious materials. Mater Sci Forum. 2019;955:44-9. https://doi.org/10.4028/www.scientific.net/MSF.955.44.

24. Dragomirová J, Palou MT, Novotný R. Effect of heavy aggregates on concrete shrinkage. In: Proc. of $6^{\text {th }}$ ICBM: international conference binders and materials"Brno $6^{\text {th }}$ Dec. 2018 , p. 44-49, ISBN 978-80-214-5567-2.

25. EN 1992-1-1 EuroCode 2: Designing of concrete structures-Part 1-1: General regulations for civil engineering.

26. Carlos A. León y León. New perspectives in mercury porosimetry. ADV COLLOID INTERFAC. 1998:76-77;341-372. https://www.sciencedirect.com/journal/advances-incolloid-and-interface-science/vol/76/suppl/C.

27. Kovler K. Why sealed concrete swells? Am Concr Inst Mater J. 1996;93(4):334-40.

28. Kim KH, Jeon SE, Kim JK, Yang S. An experimental study on thermal conductivity of concrete. Cement Concrete Res. 2003;33:363-71. https://doi.org/10.1016/S00088846(02),00965-1.

29. Khan MI. Factors affecting the thermal properties of concrete and applicability of its prediction models. Build Environ. 2002;37:607-14. https://doi.org/10.1016/S03601323(01)00061-0.

30. Bouguerra A, Laurent JP, Goual MS, Queneudec M. The measurement of the thermal conductivity of solid aggregates using the transient plane source technique. J Phys D Appl Phys. 1997;30:2900-4. https://doi.org/10.1088/0022-3727/30/20/018.

\section{Acknowledgements}

This work was supported by V4-Korea Joint Research Program on Chemistry and Chemical Engineering under the auspices of Slovak Academy of Sciences and is a part of the project No. 127102 that has been implemented with the support from the National Research, Development and Innovation Fund of Hungary, financed under the NN_17 V4-Korea funding scheme. Authors express thankful for partial financial support from APVV-15-0631, APVV-SK-KR-18-0006 and Slovak Grant Agency VEGA No. 2/0097/17. 